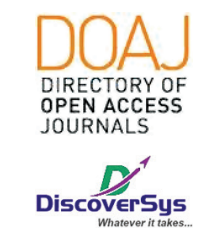

Published by DiscoverSys

\section{Evaluation of fracture on children in orthopaedic and traumatology division in Dr. Wahidin Sudirohusodo Central General Hospital Makassar January 2016-December 2017}

\author{
Robin Kurnia Wijaya, ${ }^{1 *}$ Muhammad Nasser Mustari ${ }^{2}$

\section{ABSTRACT}

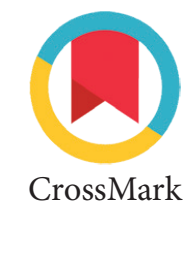

Background: Fractures in children can be caused by a long term disability and decreasing quality of life in every people that involved. Factors that affect fractures incidences must be identified so that we can create prevention management. This study aims to evaluate the fractures pattern of children in orthopaedic and traumatology in $\mathrm{dr}$. Wahidin Sudirohusodo Central General Hospital Makassar.

Methods: A cross-sectional study was conducted among children under 19 years old by collecting a medical record of patients. The prevalence and patterns of fractures were reviewed for details, such sex, range of age, causes, place of injury, single or multiple fractures, types or location of single fracture, and treatment of fractures. Data were analysed using SPSS version 17 for Windows.
Results: There were 152 children in the study, and $72.3 \%$ were boys. Most common occur at the 12-18 years age group (92.8\%), most of them were caused by traffic accidents (73.6\%). Consequently, the location in which fractures were most prevalent was the street (76.9\%). Most of them were presented as a single fracture $(72.3 \%)$ dominated by closed fracture (63.6\%), while distal radius/ulna (12.7\%) was the most common fracture sites in this study and most patients have undergone surgery for their treatment (84.8\%).

Conclusion: Most of the patients were boys and caused by traffic accidents. A single and close fracture were the most common types of fracture.
'Department of Surgery, Faculty of Medicine, Universitas Hassanudin, Makassar, Indonesia.

${ }^{2}$ Orthopaedic Division, Department of Surgery, Faculty of Medicine, Universitas Hassanudin, Makassar, Indonesia.

${ }^{*}$ Correspondence to: Robin Kurnia Wijaya; Department of Surgery, Faculty of Medicine, Universitas Hassanudin, Makassar, Indonesia;

robinkurnia@yahoo.com

Received: 2019-07-13 Accepted: 2020-01-06 Published: 2020-03-05

Keywords: Pediatric, fracture, epidemiology, orthopaedic

Cite this Article: Wijaya, R.K., Mustari, M.N. 2020. Evaluation of fracture on children in orthopaedic and traumatology division in Dr. Wahidin Sudirohusodo Central General Hospital Makassar January 2016-December 2017. Intisari Sains Medis 11(1): 132-136. D0I: 10.15562/ism.v11i1.563

\section{INTRODUCTION}

Fractures often happened in children and adult. Fracture mostly caused by trauma. ${ }^{1}$ Study conducted by Riset Kesehatan Dasar Indonesia 2013, showed that prevalence of trauma in Indonesia was $8.2 \%$, the highest number was in South Sulawesi (12.8\%), and the lowest was in Jambi (4.5\%). Fall and traffic accident were the most common cause $(40.9 \%$, and $40.6 \%$, respectively), the most common range of age by the time of accident were 15-24 years old (11.7\%) and 5-14 years old (9.7\%). Only 5.8\% of them suffered from fractures. ${ }^{2}$

The first epidemiological study about fractures in children was conducted in the late $19^{\text {th }}$ Century. This study was done by Beekman and Sulivan in New York, and Lichtenberg, Nebraska, USA, involving 2000 fractures in children cases. Landin was the first pioneer in epidemiological based study on children. 8682 fractures cases were involved in his study for over 30 years in Sweden. Landin investigated the correlation between age and gender with patterns and types of fractures.,

The risk for children to had fracture is $50 \%$ in boys and $30 \%$ in girl. The patterns of fractures in children depends on, age, gender, season, and environment, which differs in one and another region in different country. ${ }^{5-7}$ Fracture also become the most common causes of high children hospitalisation rate caused by trauma.,9

Until present, most of the research only conducted in West Country. In some developed country, trauma was the leading caused of morbidity in children. ${ }^{1,10}$ Studies about fractures in children is crucial to provide a design of prevention program for fractures incidences. ${ }^{1,10,11}$ Based on the aforementioned, the purpose of this study is to evaluate the fractures pattern of children in orthopaedic and traumatology in dr. Wahidin Sudirohusodo Central General Hospital Makassar.

\section{METHODS}

A retrospective cross-sectional study was conducted among 152 respondents from medical records. All the in-patient that diagnosed with a fracture at orthopaedic and traumatology ward in dr. Wahidin Sudirohusodo Central Hospital Makassar from January 2016 to December 2017, with age less than 19 years old were enrolled in this study. Their records were obtained from the admission files. 
Excel spreadsheet was used to perform calculations and organise the data of patient's sex, range of ages, causes, place of injury, single or multiple fractures, types of single fracture, location of single fracture, and treatment of fractures.

Based on the range of ages, patients are categorised in four grouped, infant (0-1 years old), pre-school children (2-4 years old), school children (5-11 years old), dan adolescents (12-18 years old). Causes of injury are divided into, traffic accidents, fall from height less than 1 meter, fall from height more than 1 meter, blunt trauma, and other trauma. Places of injury are also recorded, these are street, playground/ sports field, and house. In single fracture, types of fracture also divided into closed and open fracture., distribution of location of single fracture also described into 22 sites. Treatment of choice in this study divided into three. These are surgery, conservative, and refusal of medical assistance.

Data were analysed using SPSS version 17 for Windows in determining the frequency and percentage of several parameters assessed in this study. Those parameters were gender, age, causes of injury, places of injury, single/multiple fractures, open/closes fracture, sites of fracture, and treatment used in this study.

\section{RESULTS}

A total of 152 children presented with fracture during the study period. There were 126 boys (82.9\%) and 26 girls (17.1\%), giving a male to female ratio of 4.8:1 (Table 1). As shown in Table 1, the most common fracture in children occur at a range of age $12-18$ years old, 141 patients $(92.8 \%)$. In this study there were no fracture incidents at pre-school age. In addition, the most common causes of fracture was traffic accidents in 112 children $(73.6 \%)$, followed by falls below 1 meter in 21 children (13.8\%), due to falls above 1 meter in 10 children (6.6\%), due to other trauma in 8 children $(5.3 \%)$ and due to other injury in a child (0.7\%) (Table 1).

Consistant with the causes of injury, the most common place of injury was in the street (77\%), followed by house (12.5\%) and playground/ sports field (10.5\%). From 152 fracture cases, 110 (72.3\%) of them were present as a single fracture, and only $42(27.7 \%)$ of them were multiple fractures. While in single fracture group, 70 (63.6\%) of them were closed fracture, and 40 (36.4\%) were open fractures (Table 1). Besides, table 1 also shows that fractures of the distal radius/ulna are the most prevalent incidence in single fracture $(12.8 \%)$, followed by distal tibia/fibula fracture (11\%) and medial tibia/ fibula (10\%).
Around 129 (85\%) patient has undergone surgery, while $17(11.1 \%)$ were treated with conservative management. 6 (3.9\%) of them decided to refuse of medical assistant (Table 1). All patient who was agreed to undergone treatment, have a good outcome. There was no death case in this study.

\section{DISCUSSION}

In our study, the fracture was more common in boys than in girls (4.8:1), and most often occur at age $12-18$ years old $(92.8 \%)$. Some studies showed that sex didn't affect the fractures occurrences in child below 12 years old. However, as the children grew older, there was significant higher rate of fracture incidence in boys compared to girls. Most studies reported male predominance and attributed this to physiological influence of hormones at puberty, where boys would be more adventurous and would be more likely to participate in risky physical activities. This finding is consistent with the previous studies in Thailand, Pakistan, Malaysia, and Indonesia. ${ }^{10-12}$

The most common cause of fractures was a traffic accident (73.6\%). This was supported with World Report on Traffic Injury Prevention that showed, around $85 \%$ of all global road deaths, $90 \%$ of the disability-adjusted life years lost due to crashes, and $96 \%$ of all children killed worldwide as a result of road traffic injuries occur in low-income and middle-income countries. Among both children aged 5-14 years and young people aged $15-29$ years, road traffic injuries are the second-leading cause of death worldwide. ${ }^{13}$ Study conducted by Blows et al., showed that unlicensed drivers were at significantly higher risk of car crash injury than those holding a valid licence (odds ratio 11.1; 95\% confidence interval 4.2 to 29.7), which is quite common in low-income and middle-income countries like Indonesia. ${ }^{14}$ This may be due to the increased use of vehicles number is not balanced with the improvement of road safety regulations. ${ }^{15,16}$ With the climb up tren of traffic accidents over the year parallel with improving the economy and population, this problem will also show an escalation in the future. ${ }^{16,17}$

Falling was the second most common causes of fracture in this study. Around 13.8\% from a height less than 1 meter and 6.6\% from height more than 1 meter. Children at age less than 10 years old are at higher risk for falling. ${ }^{13}$ As shown in Table 1, the most common place of injury in this study is on the street, followed by house and play ground (77\%; $12.5 \% ; 10.5 \%$, respectively). This is consistent with the most common causes of fracture in this study, which is traffic accidents. Sya'ban, Fatminingrum, 
Table 1 Characteristic of respondents during the study period

\begin{tabular}{|c|c|c|}
\hline Parameters & Frequency $(n=152)$ & Percentage (\%) \\
\hline \multicolumn{3}{|l|}{ Gender (\%) } \\
\hline Boy & 126 & 82.9 \\
\hline Girl & 26 & 17.1 \\
\hline \multicolumn{3}{|l|}{ Age (years-old) } \\
\hline $0-1$ & 2 & 1.3 \\
\hline $2-4$ & 0 & 0 \\
\hline $5-11$ & 9 & 5.9 \\
\hline $12-18$ & 141 & 92.8 \\
\hline \multicolumn{3}{|l|}{ Causes of Injury (\%) } \\
\hline Traffic Accident & 112 & 73.6 \\
\hline Fall from height $<1 \mathrm{~m}$ & 21 & 13.8 \\
\hline Fall from Height $>1 \mathrm{~m}$ & 10 & 6.6 \\
\hline Blunt Trauma & 1 & 0.7 \\
\hline Other Trauma & 8 & 5.3 \\
\hline \multicolumn{3}{|l|}{ Places of Injury (\%) } \\
\hline Street & 117 & 77.0 \\
\hline Playground/ Sports Field & 16 & 10.5 \\
\hline House & 19 & 12.5 \\
\hline \multicolumn{3}{|l|}{ Number of Fractures (\%) } \\
\hline Single & 110 & 72.3 \\
\hline Multiple & 42 & 27.7 \\
\hline \multicolumn{3}{|c|}{ Types of Single Fractures $(n=110)$} \\
\hline Open & 40 & 36.4 \\
\hline Closed & 70 & 63.6 \\
\hline \multicolumn{3}{|l|}{ Sites of Fracture } \\
\hline Vertebra & 3 & 2.7 \\
\hline Clavicle & 3 & 2.7 \\
\hline Proximal Humerus & 2 & 1.8 \\
\hline Medial Humerus & 1 & 0.9 \\
\hline Distal Humerus & 0 & 0 \\
\hline Supracondyler Humerus & 1 & 0.9 \\
\hline Olecranon & 0 & 0 \\
\hline Proximal Radius/ulna & 4 & 3.6 \\
\hline Medial Radius/ulna & 7 & 6.3 \\
\hline Distal Radius/ulna & 14 & 12.7 \\
\hline Metacarpal & 3 & 2.7 \\
\hline Digiti manus & 8 & 6.2 \\
\hline Pelvis & 4 & 3.6 \\
\hline Proximal Femurl & 8 & 7.3 \\
\hline Medial Femur & 8 & 7.3 \\
\hline Supracondyler Femur & 9 & 8.2 \\
\hline Proximal Tibia/fibula & 5 & 4.5 \\
\hline Medial Tibia/fibula & 11 & 10 \\
\hline Distal Tibia/fibula & 12 & 11 \\
\hline
\end{tabular}


Table 1 Continued

\begin{tabular}{lcc}
\hline Parameters & Frequency $(\mathbf{n = 1 5 2 )}$ & Percentage (\%) \\
\hline Calcaneus & 0 & 0 \\
Metatarsal & 3 & 2.7 \\
Digiti tarsus & 4 & 3.6 \\
Treatment & & \\
Surgery & 129 & 85 \\
Conservative & 17 & 11.1 \\
Refusal of Medical Assistant & 6 & 3.9 \\
\hline
\end{tabular}

and Bayusentono found that the most common spot of falling inside the house is bed, window, and garden. While in the playground iys usually happen when they do some sports activities. ${ }^{17}$

This result is different from previous studies in other countries. Saw et al., in Malaysia, showed that the most common cause of fracture in children was falling inside the house (36.5\%), while traffic accident only $9.23 \%{ }^{1}$ While study conducted by Kaewpornsawan $\mathrm{K}$ et al., in Thailand also showed that falling inside the house was the most common cause of fracture (36\%), followed by traffic-accident $(25.2 \%) .^{10}$

Public facilities like playgrounds or parks are not well developed in many developing countries, especially Indonesia; hence it is quite logical to question their safety as well. Without proper facilities, boys were more often to make their physical activities which could be adventurous and risky. Measures to improve safety awareness at playgrounds and home environment should be carried out to reduce the risk of fractures as a whole., ${ }^{4,6,7}$

Fractures caused by road-related accidents require road safety and accident prevention programs at both the local and national levels. Home and school environments should also be prepared to prevent accidental fractures in children. ${ }^{10}$ About $72.3 \%$ fractures in this study were single fracture, and $63.6 \%$ of them were closed fracture, while only $36.4 \%$ were open fracture. A study conducted by Sharma, Ali dan Ubbot in India, also shown the same result, where $73.8 \%$ of fracture in their study were closed fracture, and open fracture was $26.2 \%$, it is also the same with study conducted in Nigeria by Igho. It is showed that types fracture depends on the level and types of trauma. For example, open fracture is related to high energy trauma that usually involved injury to other organ. ${ }^{18,19}$

Distal radius/ ulna was the most common site of single fracture in our study. Followed by distal tibia/fibula. This study was consistent with the sudy that conducted by Saw A et al., in Malaysia; Gill UN et al., in Pakistan, Kristian HN and Ardianto A, in Indonesia. ${ }^{1,11,20}$
Surgery is the most common choices of treatment for managing fractures in children in this study (85\%). This result was different from the study conducted by Nwadinigwe in Nigeria, where conservative treatment remains the treatment for managing fractures in children (67\%). ${ }^{21-23}$

\section{ETHICAL CONSIDERATION}

Ethics approval has been obtained from the ethics committee of the Faculty of Medicine, Universitas Hassanudin, Makassar, Indonesia prior to the study being conducted.

\section{CONFLICT OF INTEREST}

None

\section{FUNDING}

The authors are responsible for the funding of study without the involvement of grant, scholarship, or any other resources of funding

\section{AUTHORS CONTRIBUTION}

All of the authors are equally contributed to the study from the conceptual framework until reporting the results of study

\section{REFERENCES}

1. Saw A, Fadzilah N, Nawar M, Chua YP. Pattern of Childhood Farctures in a Developing Country. Malaysia Orthopaedic Journal. 2011;5(1):13-16.

2. Riset Kesehatan Dasar. Badan Penelitian dan Pengembangan Kesehatan Kementerian Kesehatan Republik Indonesia. Jakarta. 2013:104-106.

3. Cooper C, Dennison EM, Leufkens HGM, Bishop N, Van Staa TP. Epidemiology of Children Fractures in Britain: A Study Using the General Practice Research Database. Journal of Bone and Mineral Research. 2004;19(12):1976-1981.

4. Rennie L, Brown CM, Mok JYQ, Bettie TF. The Epidemiology of Fractures in Children. Int J Care Injured. 2007;38(117):913-922.

5. Randsborg H, Gulbrandsen P, Saltytė Benth J, Sivertsen EA, Hammer OL, Fuglesang HF, et al. Fractures in Children: epidemiology and activity-spesific fractures rates. J Bone Joint Surg Am. 2013;95(42):e42 
6. Moon RJ, Harvey NC, Curtis EM, de Vries F, van Staa T, Cooper C. Ethnic and geographic variations in the epidemiology of childhood fractures in the United Kingdom. Bone. 2016; 5(2):9-14.

7. Park MS, Chung CY, Choi IH, Kim TW, Sung KH, Lee SY, et al. Incidence patterns of pediatric and adolescent orthopaedics fractures according to age groups and season in South Korea: a population-based Study. Clin Orthop Surg. 2013; 5 (23): 161-166.

8. Wang H, Yu H, Zhou Y, Li C, Liu J, Ou L, et al. Traumatic Fractures as a Result of Falls in Children and Adolescents: A Retrospective Observational Study. Medicine (Baltimore). 2017; 96(37):e7879

9. Hedstrom EM, Svenson O, Bergstrom U, Michno P. Epidemiology of Fractures in Children and Adolescents. Acta Orthopaedica. 2010; 81(1):148-153.

10. Kaewpornsawan K, Sukvanich P, Tujinnda H, Eamsobhana P. Prevalence and Pattern of Fractures in Children. J Med Assoc Thai. 2014;97(9):116-S120.

11. Gill UN. Epidemiology of Orthoapedics Fractures in Under-Developed Country Due to Trauma, A Retrospective Study. JPOA. 2016;28(2):64-66.

12. Kristian HN, Ardianto A. Epidemiology of Fractures and Dislocation in Children. Folia Medica Indonesiana. 2017;53(1):81-85.

13. Peden M. World report on road traffic injury prevention. Geneva: World Health Organization. 2004.

14. Blows S, Ivers R, Connor J, Ameratunga S, Woodward M, Norton R. Unlicensed Drivers and Car Crash Injury. Traffic Injury Prevention. 2005;6(3):230-234.

15. Nantulya V, Reich MR. The Neglected Epidemic: Road Traffic Injuries in Developing Countries. BMJ. 2002;324(7346):1139-41.
16. Nwadinigwe CU, Ihezei CO, Iyidiobi EC. Fractures in Children. Nigerian Journal of Medicine. 2006;15(1):81-84.

17. Sya'ban SN, Fatminingrum W, Byusentono S. The Profile of Fractures in Patients Under 17 years od Age at RSUD dr. Soetomo in The Period of 2013-2014. Journal of Orthopaedic and Traumatology. 2017;6(1):32-21.

18. Igho O, Isaac O, Eronimeh O. Road Traffic Accidents and Bone Fractures in Ughelli, Nigeria. IOSR Journal of Dental and Medical Sciences, 2015;14(4):21-25.

19. Sharma R, Ali L, Ubbot M. The Epidemiology of Fractures and Dislocations at District Hospital Kathua (J\&K). International Journal of Current Medical Science \& Practice. 2006;14(2):114-117.

20. Kristian HN, Ardianto A. Epidemiology of Fractures and Dislocation in Children. Folia Medica Indonesiana. 2017;53(1):81-85.

21. Rasjad, C. Fraktur dan Dislokasi Sendi pada Anak, Dalam: Pengantar Ilmu Bedah Ortopedi Edisi ketiga. Yarsif Watampone; 2007:70-380.

22. Solomon L, Warwick D, Nayagam S. Apley's System of Orthopaedics and Fractures Ninth Edition. United Kingdom: Hodder Arnold. 2010:627-907.

23. Schalamon J, Dampf S, Singer G, Ainoedhofer $H$, Petnehazy T, Hoellwarth ME, et al. Evaluation of Fracture in Chilfren and Adolescents in a Level 1 Trauma Center in Austria. J Trauma. 2011;71(2):E19-25.

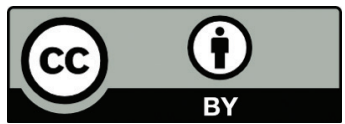

This work is licensed under a Creative Commons Attribution 